\title{
Seismic monitoring of precursory fracture signals from a destructive rockfall in the Vorarlberg Alps, Austria
}

\author{
M. Walter, U. Schwaderer, and M. Joswig \\ Institute for Geophysics, University of Stuttgart, 70174 Stuttgart, Germany \\ Correspondence to: M. Joswig (manfred.joswig@geophys.uni-stuttgart.de)
}

Received: 7 March 2012 - Revised: 2 July 2012 - Accepted: 11 October 2012 - Published: 29 November 2012

\begin{abstract}
In this study we describe the seismic analysis of precursory patterns of a rockfall in the "Rappenlochschlucht", a gorge located in the Vorarlberg Alps, Austria. The rockfall with an estimated volume of $15000 \mathrm{~m}^{3}$ occurred on 10 May 2011 (10:48:43 UTC) and destroyed a massive bridge construction. Fortunately, the rockfall did not cause any casualties.
\end{abstract}

A permanent seismic network consisting of three seismic small arrays was installed in July 2009 in $5 \mathrm{~km}$ distance to the gorge, at the Heumoes slope, in order to detect and locate slope-related fracture processes within a radius of a few hundred meters. By chance, the rockfall with an estimated equivalent local magnitude of $M_{\mathrm{L} \text {,eq }}=2.3$ was recorded by the seismic network. We observed several smaller rockfall events up to three hours, and 12 fracture signals up to five hours prior to the rockfall. The smaller rockfalls and the fractures were both located in the vicinity of the source area where the main event emerged, applying absolute and relative localization methods.

These specific types of fracture signals located near by the gorge "Rappenlochschlucht" have never been observed in almost two years of permanent seismic monitoring. We interpret these fractures with magnitudes between $M_{\mathrm{L}}=0.4$ and -0.5 as precursory signals of the main rockfall event. The observed fractures and the weaker rockfalls are sequences of initial stress relief within the rock mass and mass transferring processes, respectively, finally causing the destructive main rockfall event.

To investigate possible triggers of the destructive rockfall event, several meteorological and hydrological data as well as the local seismicity during that period of time were analyzed and discussed in detail in this study. Unfortunately, no triggering factor of the rockfall event was identified, and remains therefore unknown.

\section{Introduction}

This section gives an outline of the geographical and geological setting of the "Rappenlochschlucht" gorge, were the rockfall occurred. Additionally to the rockfall event, seismic monitoring techniques to analyze signals related to mass movements in general and the permanent seismic network at Heumoes slope, which was used in this study, are described in this section.

\subsection{Geographical and geological setting}

The rockfall occurred in the "Rappenlochschlucht" gorge, which is a popular hiking area with thousands of tourists visiting yearly. The gorge is situated in the northern Alpine upland, close to the city of Dornbirn, about $20 \mathrm{~km}$ south of Bregenz in Vorarlberg, Austria (Fig. 1). The gorge was formed by predecessors of today's "Ebniterach", a river at the end of the Wuerm glacial stage, around $11700 \mathrm{yr}$ ago (Oberhauser, 1980). Today, the "Ebniterach"، river runs through the gorge, and still erodes the solid rock. Together with the "Dornbirnerach", these rivers drain the entire mountainous region.

From the northern Alpine flysch zone, the gorge leads with a deep-seated gain and steep faces into the first hard rock masses of the Alps. The surrounding bedrock is characterized by seasonal layers of upper cretaceous sediments, mainly marls and limestone, which generally feature a very low hydraulic conductivity (Oberhauser, 1980). In contrast to the limestone, the marls are highly susceptible to erosion due to their lower degree of consolidation. Both mentioned layers belong to the geological Alpine orogenesis unit of the Helveticum.

Figure 1 shows the geographical set up of the area of the "Rappenlochschlucht" gorge and the Heumoes slope, where the permanent seismic network is installed, and the 


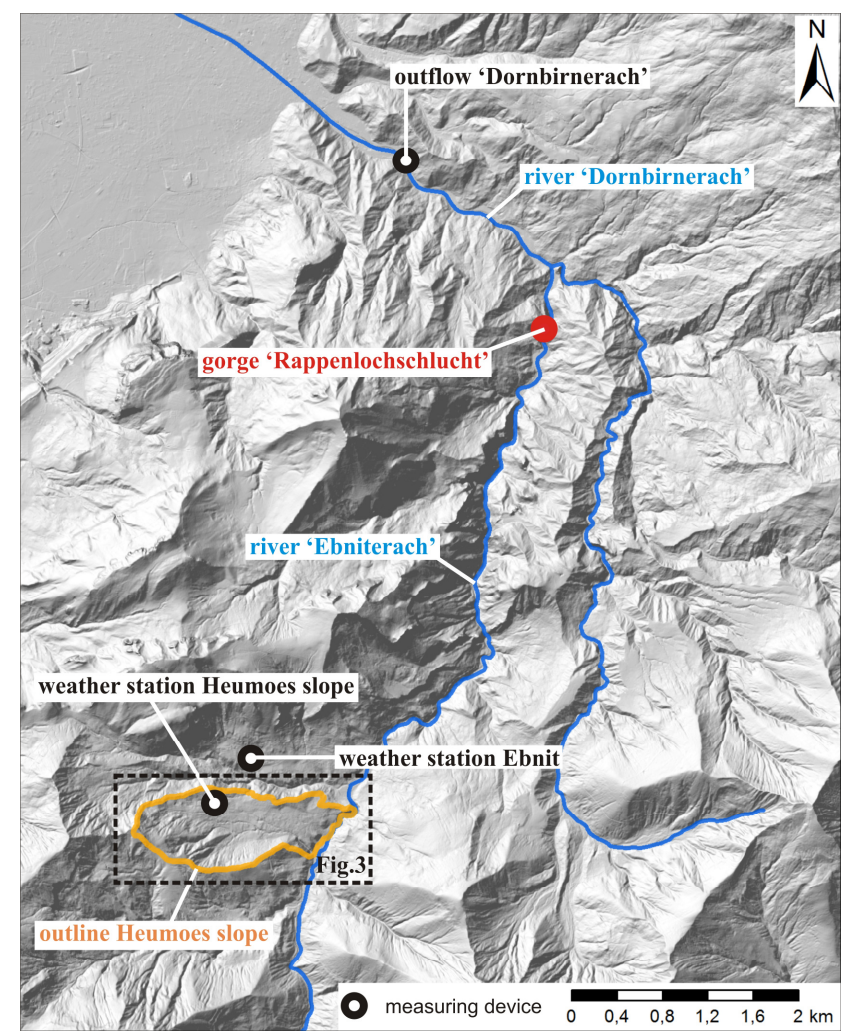

Fig. 1. Geographical overview of the area of the "Rappenlochschlucht" gorge and locations of the used meteorological and hydrological stations as well as the outline of the Heumoes slope where the seismic stations were installed (Fig. 3), mapped on an Airborne Laser Scan digital terrain model (2002-2005, by courtesy of the Land Vorarlberg).

meteorological and hydrological stations which were used to analyze possible triggers of the rockfall event.

\subsection{The rockfall event on 10 May 2011}

On 10 May 2011 (10:48:00 UTC), a huge rockfall occurred in the "Rappenlochschlucht" gorge and destroyed a massive bridge construction which has to be crossed on the only road to the higher located village of Ebnit (Fig. 1). Fortunately, the rockfall did not cause any casualties. The rockfall was initiated by rock masses which quarried out of the rock massif along a width between 40 and $50 \mathrm{~m}$. The volume of the rockfall is estimated to be around $15000 \mathrm{~m}^{3}$. The rockfall not only destroyed the bridge on a length of around $30 \mathrm{~m}$, but also covered a hiking trail which leads through the gorge with up to $20 \mathrm{~m}$ of rock blocks (Fig. 2). The reconstruction of the bridge by the Federal Armed Forces of Austria was finished on 16 June 2011, and was associated with enormous financial costs. Today, the gorge is still closed for tourists; experts from local authorities will wait for at least one freezing season before the gorge will be open for visits again. The described rockfall properties were published in the local press.
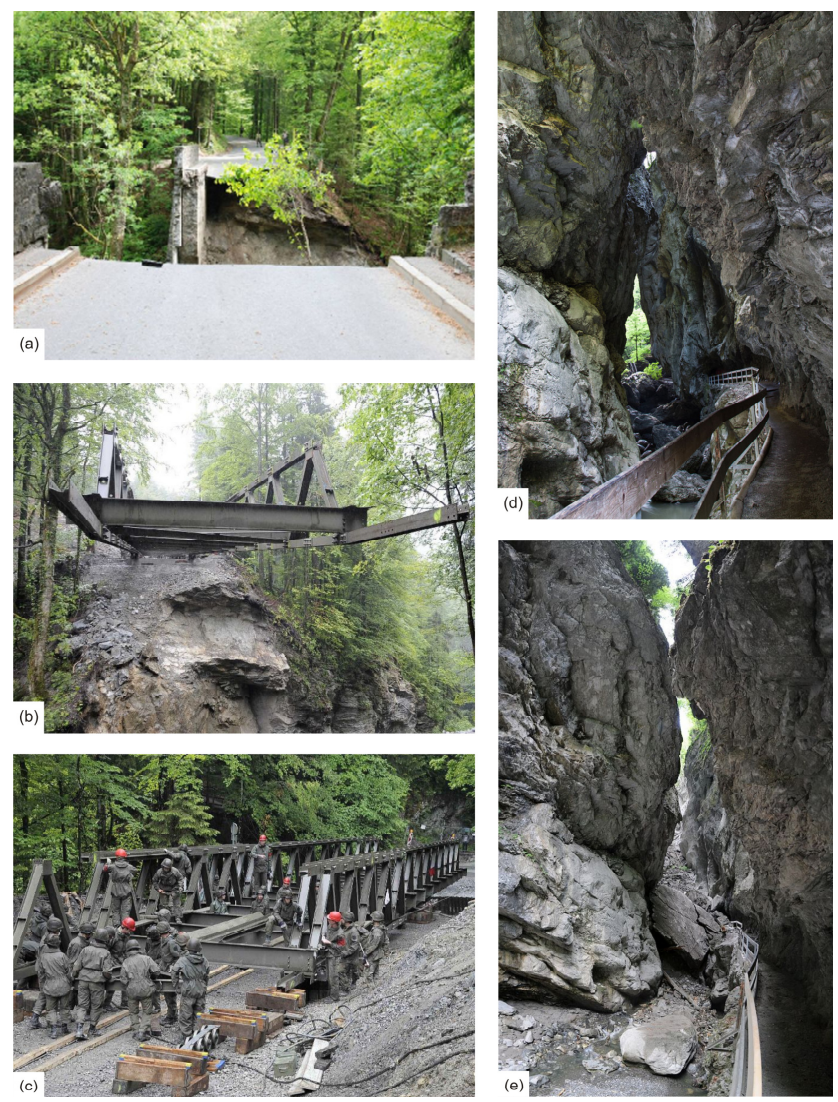

Fig. 2. Impact of the destructive rockfall: (a) the destructed bridge (photo: Stefan Hoch, source: www.bmlv.gv.at); (b and c) reconstruction of the bridge by the Federal Armed Forces of Austria (photos: Sigi Schwärzler, source: www.bmlv.gv.at); (d) view into the gorge in 2010 before the rockfall occurred (photo: Bernhard Mäser) and (e) two days after the rockfall event on 12 May 2011 (photo: Friedrich Böhringer).

\subsection{The permanent seismic network}

The rockfall occurred in a distance of about five kilometres in a north-eastern direction to the Heumoes slope, which is the actual focus of the passive seismic investigations. At the Heumoes slope, a permanent seismic network consisting of three seismic small arrays was installed in July 2009 in order to analyze the spatio-temporal occurrence of slope-related fracture events with local magnitudes of $M_{\mathrm{L}}<0.0$ (Walter and Joswig, 2008; Walter et al., 2011) applying the method Nanoseismic Monitoring (Joswig, 2008). As the seismic network was originally installed to monitor dynamic processes related to the creeping of the Heumoes slope in a few hundred meters distance, the seismic arrays are also located in a distance of a few hundred meters to each other (Fig. 3). Each small array, i.e. SNS (Seismic Navigating System), consists of a central three component seismometer station and three outer one component satellite stations in a distance of around $25 \mathrm{~m}$ to the central station. The seismic data is recorded in 


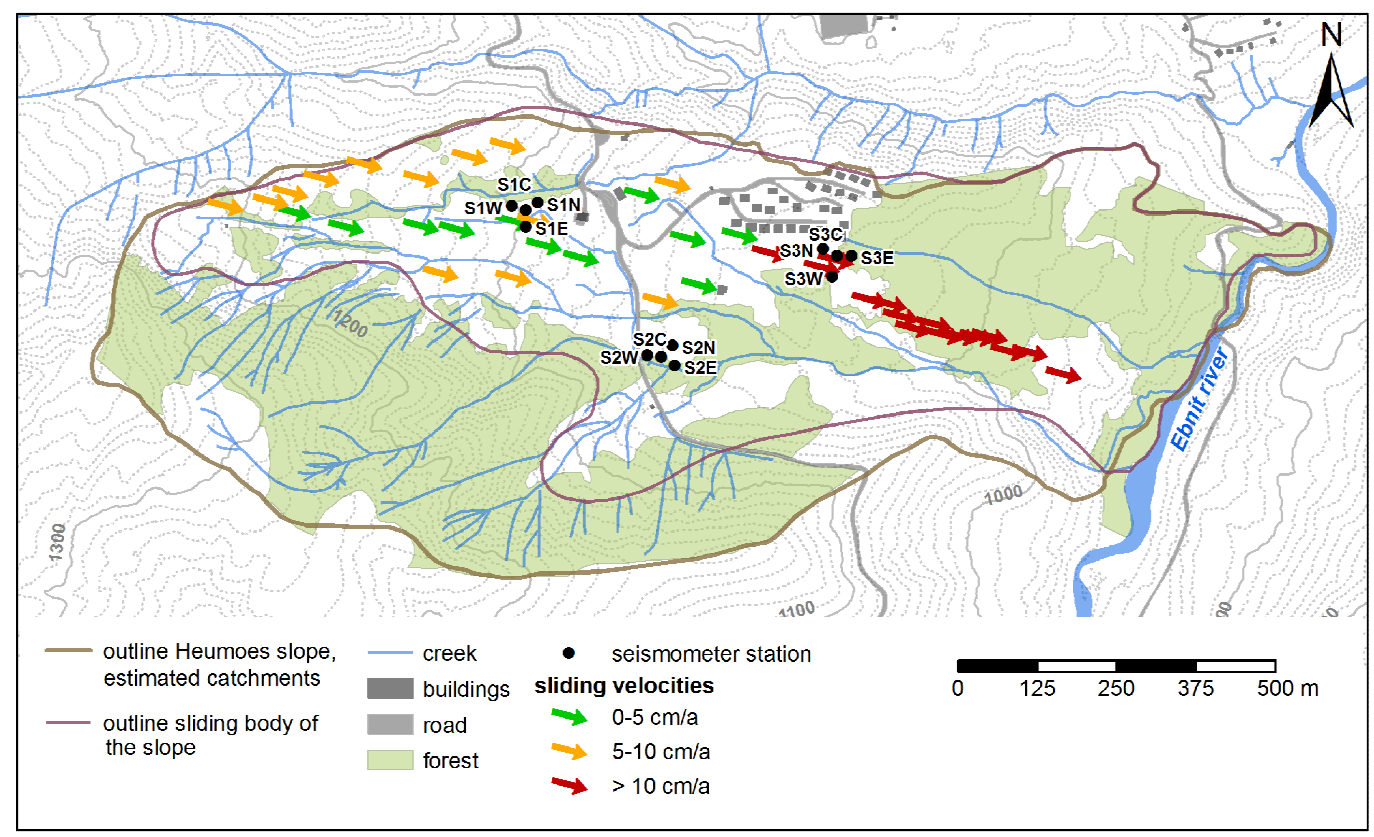

Fig. 3. General set up of the Heumoes slope, average sliding velocities (after Depenthal and Schmitt, 2003), and seismometer stations of the permanent seismic network.

a continuous mode with a preset sampling rate of $400 \mathrm{~Hz}$. Due to the low epicentral distance of about five kilometres, the rockfall event at the "Rappenlochschlucht" gorge was recorded by our network as well as any other weak seismicity in the vicinity of the arrays.

\subsection{Seismic monitoring of signals related to mass movements}

Strong rain events not only trigger morphological processes, but also influence the dynamics in the upper earth's crust (Husen et al., 2007). Rainfall-triggered earthquakes with magnitudes $M_{\mathrm{L}}>0.0$ in a depth of a few kilometers were observed in the Swiss Alps (Husen et al., 2007) and in a mountain area in Germany (Hainzl et al., 2006). On a much smaller scale, fracture processes on landslides, with magnitudes of $M_{\mathrm{L}}<0.0$, were observed in several studies by advanced seismic monitoring technics. Fracture processes on landslides consisting of hard rock (fragments) were monitored by, for example, Brückl and Mertl (2006) in the Austrian Alps, Spillmann et al. (2007) in the Swiss Alps, Helmstetter and Garambois (2010) at a rockslide, Got et al. (2010) and Levy et al. (2011) at rock columns, both in the French Alps, and Roth et al. (2005) at the Aknes fjord in Norway. Studies of seismic monitoring of soft rock-landslides were conducted at the Heumoes slope, Austria (Walter and Joswig, 2008, 2009; Walter et al., 2011), at the mudslide in Super-Sauze, French Alps (Walter et al., 2009, 2011), and at the Slumgullion landslide, Colorado, US (Gomberg et al., 1995, 2011). The most similar studies to ours documented in the literature are the ones of Got et al. (2010) and Levy et al. (2011). In these studies the locations of possible rock collapse were well known and therefore the area of interest has been instrumented satisfactorily with dense seismic and geotechnical stations. Compared to these studies, the investigated rockfall at the "Rappenlochschlucht" gorge was monitored by a seismic network which was not especially designed to analyze seismic signals from that area.

In only a few of these studies a triggering influence of rainfall to the generation of slope-related seismicity was observed. At Heumoes slope, rainfall-induced fracture processes were observed in September 2005 (Walter and Joswig, 2008; Walter et al., 2011); a few weeks after an intense rainfall event with $240 \mathrm{~mm}$ in $24 \mathrm{~h}$ in August 2005, where the slope material was still highly water saturated and therefore weak rainfall events led to fracture generation. Helmstetter and Garambois (2010) observed a strong coupling of rainfall and the generation of fracture processes in the French Alps, while, for example, Spillmann et al. (2007) could not determine a rainfall-induced generation of fracture processes on a rockslide in the Swiss Alps. Levy et al. (2011) observed on a rock column in the French Alps that the largest numbers of events fit with minima in the temperature curve, after severe temperature drops. This result suggests a temperature control on rupture events and fracturing, what is supported by resonance frequency analysis (Levy et al., 2010). 

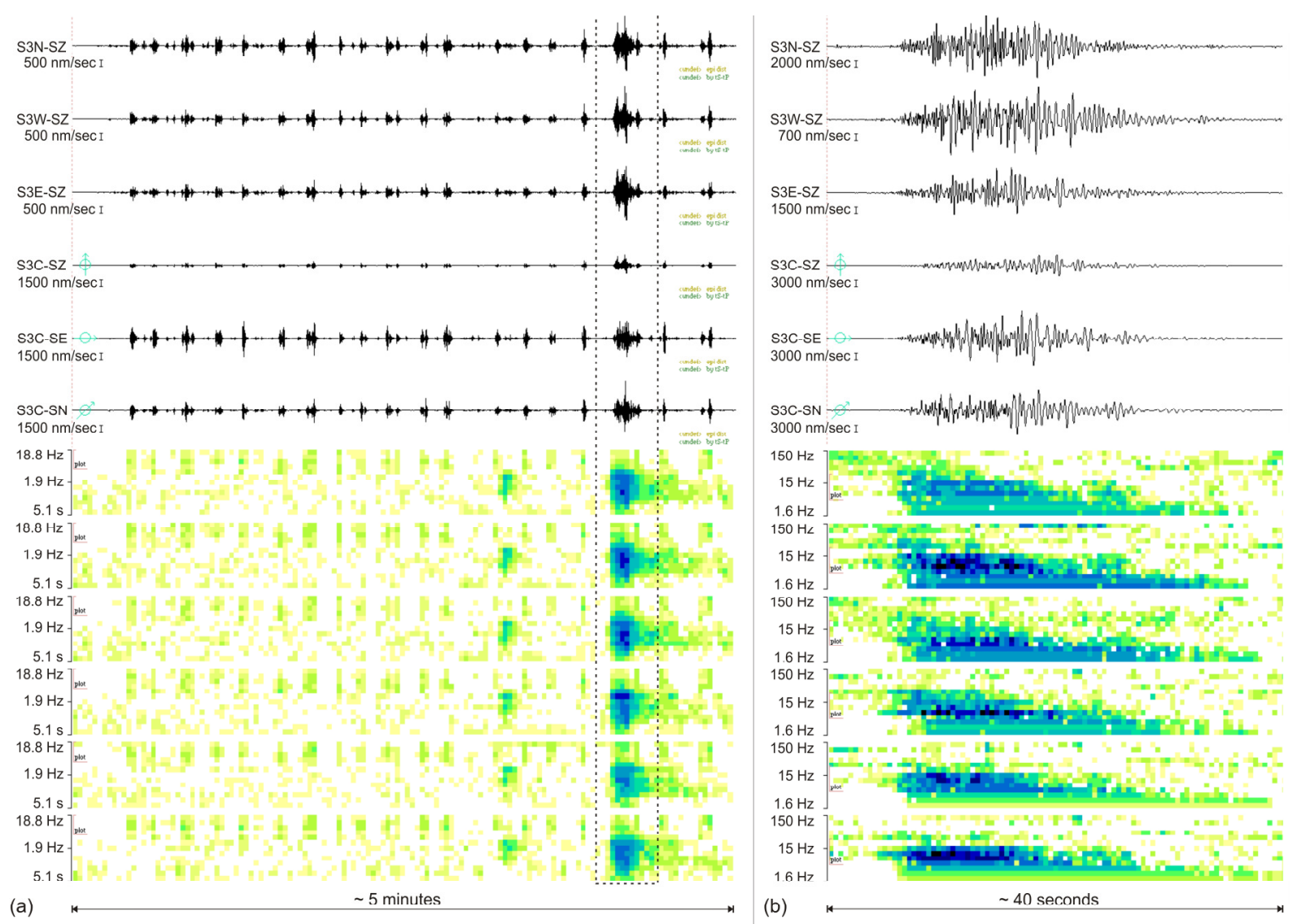

Fig. 4. Waveforms and sonograms of the destructive rockfall event on 10 May 2011, recorded with SNS 3 (Fig. 3): the upper three traces belong to the three outer 1c-stations, the lower three traces represent the 3c-central station. (a) signal of the entire rockfall sequence; (b) zoom of the signal, when the bridge was destroyed. Note the different time and amplitude scales.

\section{Seismic monitoring of rockfall-related processes}

This section describes the analysis of two different types of seismic signals related to the rockfall event: the signals of the rockfall itself, and signals which were identified to be precursory fractures. Both types of signals were located using the standard 1-D IASP91 Earth Reference Model (Kennett and Engdahl, 1991) of the International Association of Seismology and Physics of the Earth's Interior (IASPEI).

\subsection{Seismic signals of the rockfall event}

The destructive rockfall event was recorded by our seismic stations at the Heumoes slope in a distance of about five kilometers (Figs. 1 and 3). Figure 4 shows the waveforms and sonograms (Joswig, 2008) of the recorded rockfall event with duration of about $5 \mathrm{~min}$. The signals show remarkable similarities to "avalanche" signals which were recorded at the mudslide in Super-Sauze (Walter and Joswig, 2009; Walter et al., 2012; Fig. 5) and which were generated by small rockfalls in the source area of the mudslide. Figure 5 shows typical waveforms and sonograms of a rockfall event recorded and visually observed at the mudslide in Super-Sauze in July 2008. The broadband spikes represent the impact of blocks, while the low-frequency noise-band represents the flow of fine-grained material.

At Heumoes slope, these "avalanche" signals have never been observed in nearly two years of permanent seismic monitoring. Compared to the fracture signals observed at Heumoes slope (Fig. 6), the higher frequencies of the rockfall signals are damped due to the larger epicentral distance and the superficial source. The signal energy prevails in frequencies up to around $20 \mathrm{~Hz}$, no separated signal phases can be identified. The rockfall signals were located by the use of the software HypoLine (Joswig, 2008). The software implements array methods for signal location based on the generation of hyperbolae for any $t p-t p$ difference between two distinct station onset times, and array beams for related phases of the small arrays (Joswig, 2008). Beside the signal of the main rockfall event itself, the signals of two further, much weaker, rockfalls were identified and located as well. These two events occurred at 06:52:16 (UTC) and at 09:00:30 (UTC), some hours before the main event occurred at 10:48:43 (UTC) on 10 May 2011 (Figs. 7 and 8). The 


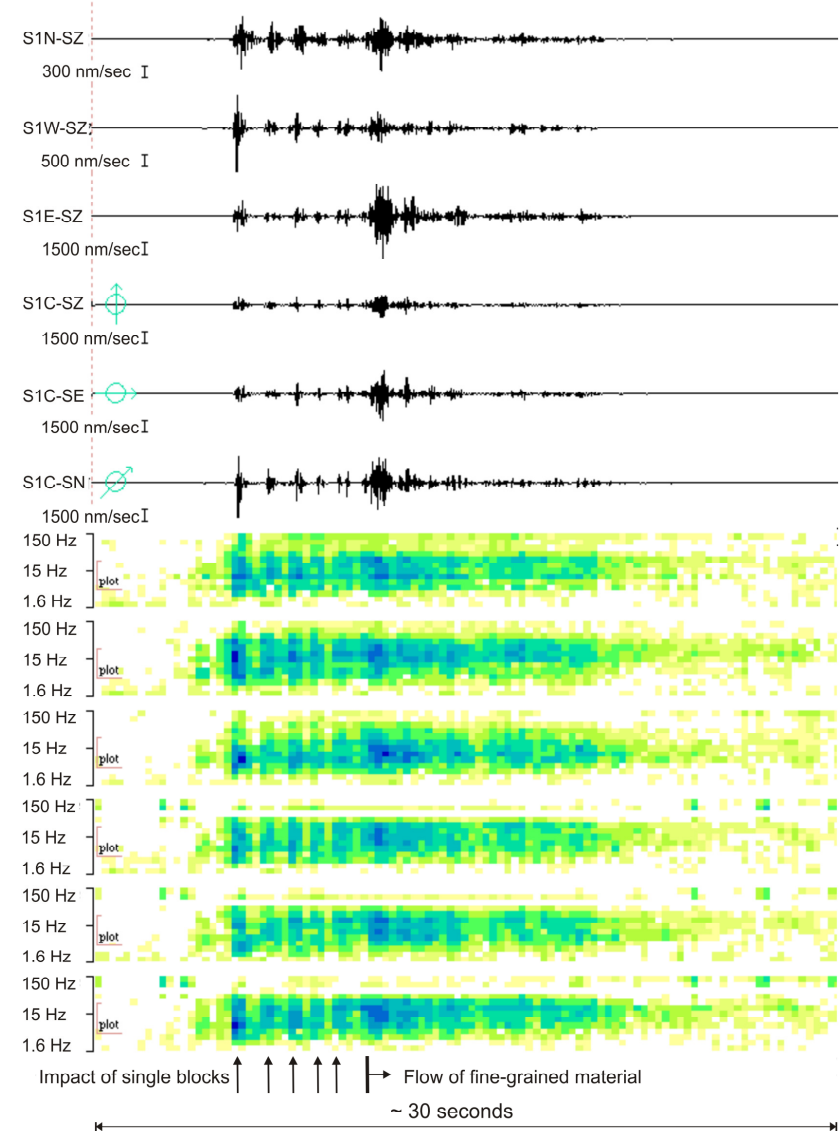

Fig. 5. Typical waveforms and sonograms of a rockfall event recorded in Super-Sauze with one single SNS: the upper three traces belong to the three outer 1c-stations, the lower three traces represent the 3c-central station (modified after Walter et al., 2012).

duration of these two events is five and seven minutes, respectively. As the location of the main event was well known, influences to the location method, e.g. chosen underground model, could be calibrated. All the rockfall signals were located in the vicinity of the "Rappenlochschlucht" gorge (Fig. 9). The used localization method is fully described in Joswig (2008).

We quantified the energy release of the rockfalls by the estimation of an equivalent local magnitude using the distancecorrelation curve for low-distance events after Joswig (2008) and Wust-Bloch and Joswig (2006). We determined the average peak-to-peak amplitude of the signal and estimated an equivalent local magnitude of the main rockfall event to be around $M_{\mathrm{L}, \mathrm{eq}}=2.3$. The magnitudes of the weaker rockfalls were both estimated to be around $M_{\mathrm{L}, \mathrm{eq}}=0.0$, so approximately two orders of magnitudes weaker than the destructive main event, which corresponds to a factor of about $10^{4}$ of released energy.

\subsection{Seismic signals of precursory fractures}

Beside the described "avalanche" signals of the rockfall events, we observed 12 signals which show similar waveforms and sonogram patterns compared to the observed fracture processes generated at Heumoes slope and recorded signals of local earthquakes from the seismo-tectonic activity of the nearby Upper Rhine valley (Fig. 6). The signals, with duration of a few seconds, show a high-frequency P-onset up to about $150 \mathrm{~Hz}$, while the later arriving phases prevail in lower frequencies between $10-30 \mathrm{~Hz}$. The common signal properties result in similar sonogram patterns which allow signal identification. But these fracture signals are characterized by significant differences compared to the fracture processes generated at Heumoes slope. Due to the low epicentral distance of a few hundred meters of the events generated at Heumoes slope, the apparent velocity of these events vary between 2.5 and $3.0 \mathrm{~km} \mathrm{~s}^{-1}$. By contrast, the apparent velocities of the precursory fractures from the "Rappenlochschlucht" gorge in about $5 \mathrm{~km}$ distance, vary between 4.5 and $5.0 \mathrm{~km} \mathrm{~s}^{-1}$ and show higher $t s-t p$ times. The $t s$ - $t p$ time of the fracture events recorded on 10 May 2011 is throughout around $1 \mathrm{~s}$, while the $t s$ - $t p$ times of the fracture events generated at the Heumoes slope vary between 0.1 and $0.2 \mathrm{~s}$. The 5 to 10 times higher $t s$ - $t p$ time-difference of these signals compared to the ones generated at the Heumoes slope and the higher apparent velocities indicate a higher epicentral source distance. Therefore, the fracture signals recorded on 10 May 2011 are not related to any dynamic processes of the Heumoes slope. Comparable to the rockfall signals, fracture signals with these signal properties have also never been observed in nearly two years of permanent seismic monitoring at Heumoes slope. Figure 6 shows typical waveforms and sonograms of a signal of the rockfall event, a fracture process at Heumoes slope and a weak local earthquake. All the events were recorded by the permanent network installed at the creeping Heumoes slope (Fig. 3).

The temporal occurrence of these signals is remarkable: the first events occurred around $5 \mathrm{~h}$ before the destructive rockfall was initiated, the last one just 15 min before rockfall generation (Figs. 7 and 8). Figure 7 shows the sonograms of $\sim 6 \mathrm{~h}$ of continuous data before main rockfall occurrence, recorded with station S1N (Fig. 3). Highlighted are local noise transient, the first rockfall event, a typical fracture signal, a teleseismic event and the main rockfall event. Figure 8 shows the temporal occurrence of both types of seismic signals, precursory fractures and rockfall events, with their (estimated) magnitudes. Remarkable is that the vast majority of observed fractures are temporarily clustered and occurred up to approximately one hour before rockfall occurrence.

The signals were located using the same procedures used for localization of the rockfall events; additionally, the $t s$ $t p$ times were considered as these signals show clear phaseonsets. All the fracture events recorded on 10 May 2011 were located in the vicinity of the "Rappenlochschlucht" gorge 

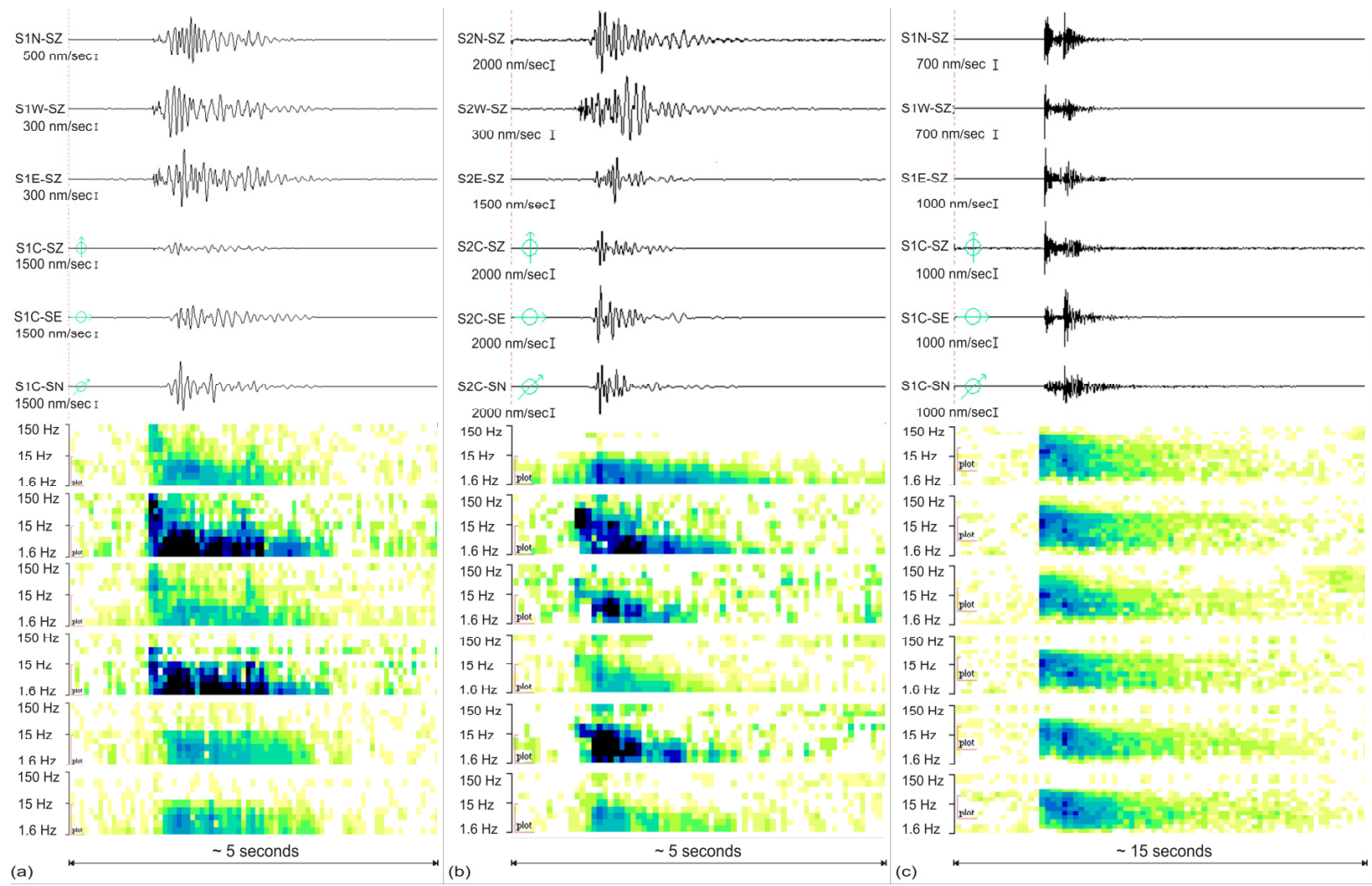

Fig. 6. Typical waveforms and sonograms of precursory fracture signals, fracture processes generated at Heumoes slope and local earthquakes recorded with one single SNS: the upper three traces belong to the three outer 1c-stations, the lower three traces represent the $3 \mathrm{c}$ central station. (a) precursory fracture $M_{\mathrm{L}}=-0.1 \mathrm{in} \sim 5 \mathrm{~km}$ distance, recorded with SNS 1 (Fig. 3); (b) fracture signal $M_{\mathrm{L}}=-1.4$ in $\sim 180 \mathrm{~m}$ distance, generated at the Heumoes landslide, Austria, recorded with SNS 2 (Fig. 3); (c) local earthquake $M_{\mathrm{L}}=2.0$ in $\sim 15 \mathrm{~km}$ distance to Heumoes slope, recorded with SNS 1 (Fig. 3). Note the different time scales.

(Fig. 9). The source depth could not be evaluated due to the sparse station distribution. Both, the temporal occurrence of the fractures, and the fact, that they are located in the vicinity of the gorge, indicate that these fractures mark precursory events of the destructive rockfall event.

The location accuracy of the absolute localization method in this case is limited due to the very low azimuthal coverage, which is approximately between $208^{\circ}-213^{\circ}$ to the source area (Fig. 9) as the network was originally not designed for seismic event analysis from that area. The location uncertainty can be generally estimated to be about $10 \%$ of the epicentral distance, in this study up to $500 \mathrm{~m}$. This location uncertainty runs in accordance to prior applications of Nanoseismic Monitoring using seismic small arrays. Häge and Joswig (2010) investigated the location improvements by relative localization methods. They compared the relative localization using the software HypoLine, which was also used in this study, with master event technics after Deichmann and Giardini (2009) and location methods based on double-difference algorithms after Kahn (2008). The results show that the relative localization improves the absolute location method and run in accordance to comparable location methods. As similar travel paths of these fracture signals can be assumed, the relative location method was applied in this study as well. The fracture signal with the highest signal-to-noise ratio was determined to be the master event and was located using the absolute localization approach. The remaining fracture events were located relative to the localization result of the master event afterwards. Figure 9 shows, additionally to the absolute localizations, the epicenters of the fractures applying the master event technic. As shown in Fig. 9, the results of the master event localization are much more spatially clustered in the vicinity of the "Rappenlochschlucht" gorge than the epicenters of the absolute localization.

We therefore assume that these signals were generated in the massive rock body by weak fracture processes which in summary caused the destructive rockfall event. This assumption is supported by the fact that these fractures occurred temporarily separated as discrete events. The tumbling and falling of single rock blocks would generate sequences of signals comparable to the described "avalanche" signals. Therefore, this possibility of source process can be excluded. The 


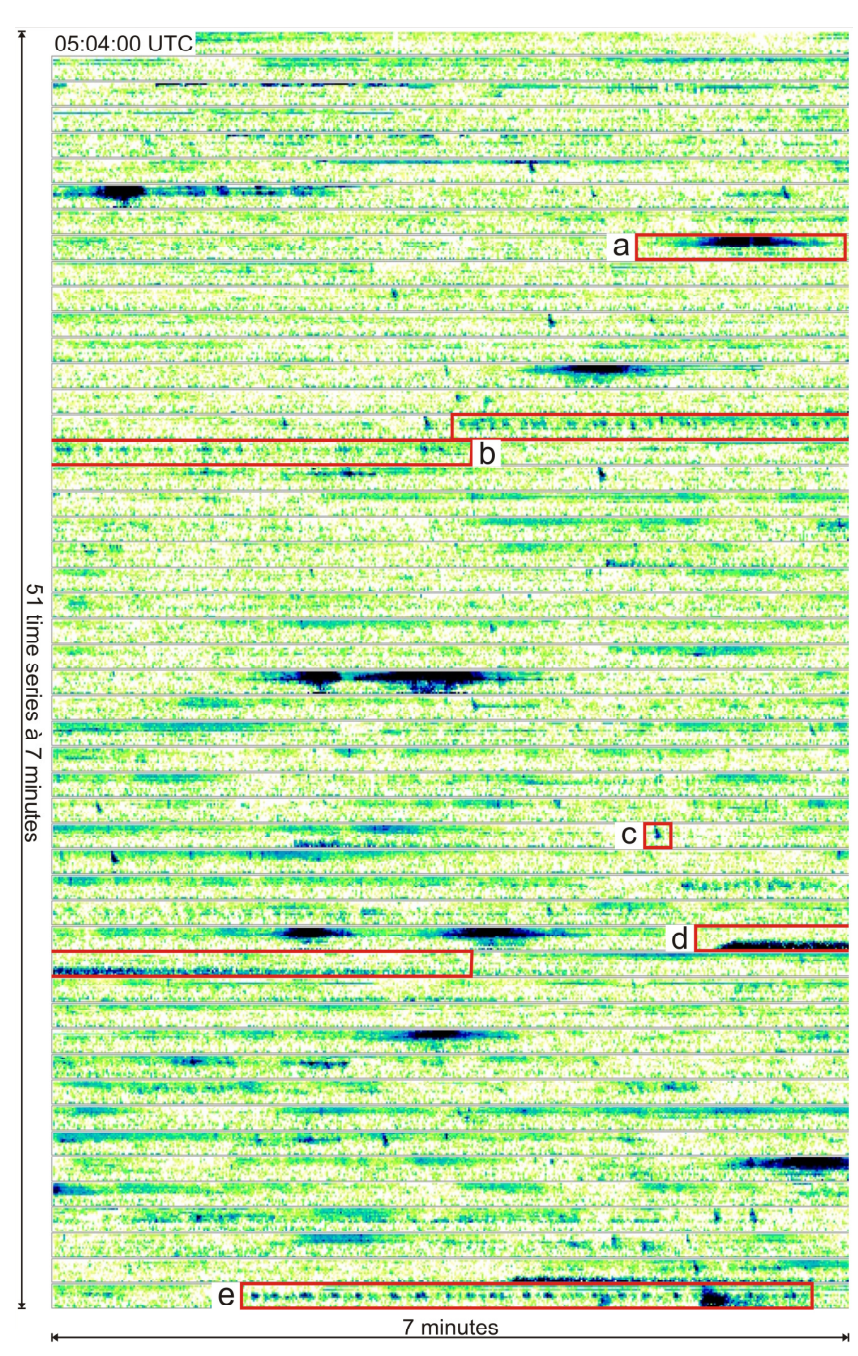

Fig. 7. Sonograms of station $\operatorname{S1N}$ (Fig. 3) showing $\sim 6$ h of continuous data before main rockfall occurrence (data resampled). (a) local noise transient, (b) first rockfall event, (c) fracture signal, (d) teleseismic event, (e) main rockfall event.

magnitude range of the precursory fractures is estimated to be $-0.5<M_{\mathrm{L}}<0.4$.

\section{Analysis of possible trigger mechanisms}

Possible trigger mechanisms of the observed rockfall event at the "Rappenlochschlucht" gorge on 10 May 2011 are analyzed and discussed in this chapter.

\subsection{Conventional triggering factors of mass movements}

Mass movements in mountainous areas can be triggered by the relative change of thermal, hydrologic or mechanical conditions, mostly related to abrupt meteorological changes, e.g. during strong rain events or snow melting periods (Kääb et al., 2005). These influences can cause significant changes

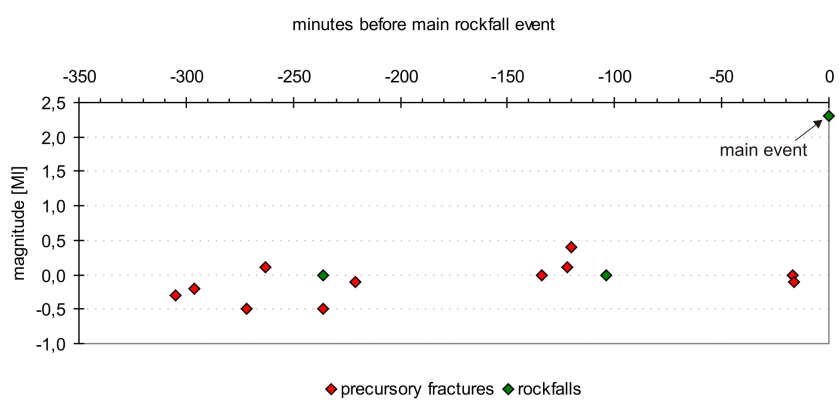

Fig. 8. Temporal occurrence of precursory fractures (red) and rockfall sequences (green) before the main rockfall event occurred, with their local magnitudes (fractures) and estimated local magnitudes (rockfalls), respectively.

of material properties of mountain slopes and forces their destabilization. Despite the fact that different influences to slope stability were observed in several studies, the majority of mass movements in general are triggered by extreme rainfall events (Tsaparas et al., 2002; van Asch et al., 1999), rockfalls are often triggered by freeze/thaw cycles, or by a combination of both.

The influence of thermal changes to rock slope stability is observed by, for example, Harris et al. (2009). The freeze/thaw weathering leads to two different effects: on the one hand, frozen water expands to an around $9 \%$ higher volume and promotes the fracturing of rock masses. On the other hand, frozen rock fractures are more stabilized due to the higher shear and tensile strength of ice (e.g. Gruber and Haeberli, 2007). The influence of the snow cover arises largely from its low thermal conductivity in dependence to its density and microstructure (Fierz and Lehning, 2001; Luetschg and Haeberli, 2005), its high surface albedo, and the latent energy provided during snow melting (Mellor, 1977; Sturm et al., 1997; Zhang, 2005). The frost penetration depths as well as a possible snow cover are directly linked to the topography of the respective slope. On planer slopes, a snow cover of more than $\sim 60-80 \mathrm{~cm}$ marks an effective thermal insulation that the frost is not able to penetrate in higher depths (Keller and Gubler, 1993; Hanson and Hoelzle, 2004). On steep slopes, the frost penetration is generally stronger due to the usually minor snow cover (Gruber and Haeberli, 2007).

Especially on rock slopes, a high frequency of frost cycles is likely to be most effective for the spalling of rock fragments (up to block size) in the uppermost parts of the solid rock (Matsuoka, 1994). But, the number of effective freezethaw cycles is reduced, if there is no water available (Prick, 2003). Rockfalls with large boulders tend to occur in association to progressive seasonal thaw penetration and/or refreezing of melt water (Rapp, 1960; Matsuoka and Sakai, 1999; Stoffel et al., 2005). Nevertheless, the ice growth in preexisting fractures reduces the stability of steep rock masses by the widening of fractures and thus preparing the way for 


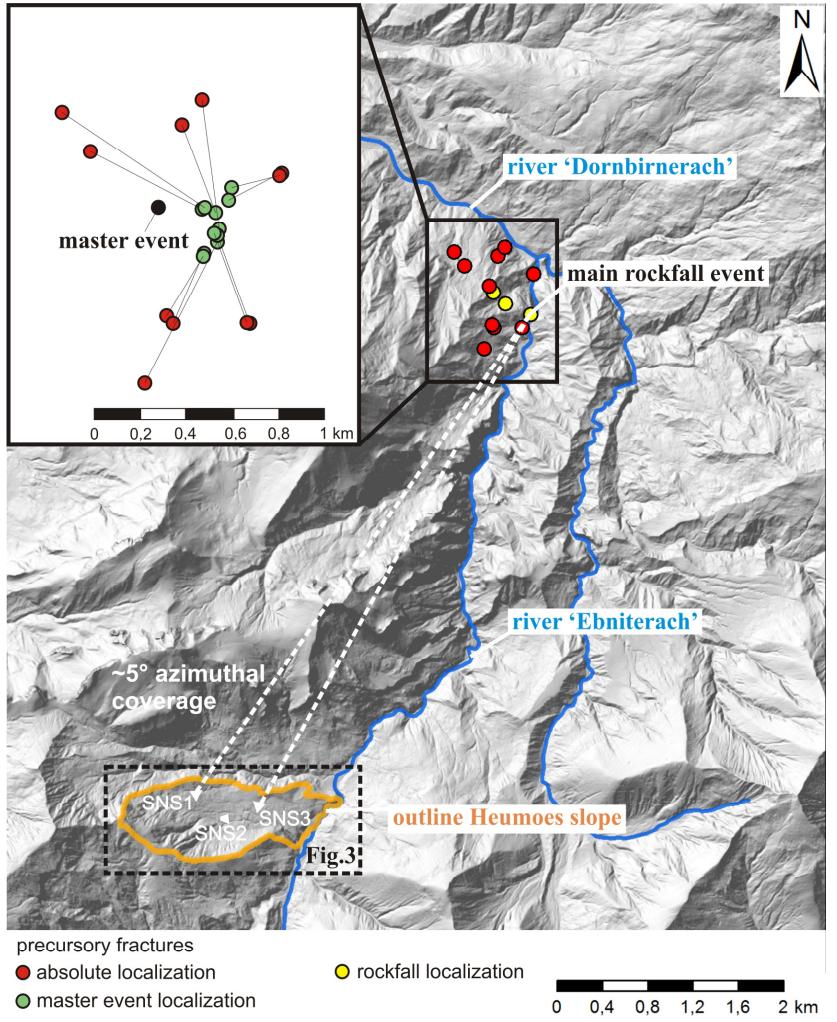

Fig. 9. Epicenters of the located rockfall events and precursory fractures mapped on an Airborne Laser Scan digital terrain model (2002-2005, by courtesy of the Land Vorarlberg).

failure during degradation, or by expanding fractures to a critical value, either slowly or in response to temperature changes (Gruber and Haeberli, 2007).

Hydrological changes mark the most common triggering factor of mass movements, especially of landslides. On soft rock-landslides, the hydrological properties of landslide material control the shear strength and the effective stress distribution within the landslide body. Rainfall and the subsequent redistribution of water within the system are the most prominent control on both of these factors, especially on landslides consisting of weak sediments (e.g. van Asch et al., 1999; Tsaparas et al., 2002). The direct coupling of rainfall, fast water infiltration, rise of pore water pressure in the subsurface and higher displacements on the slope's surface was observed by, for example, Lindenmaier et al. (2005), Travelletti et al. (2008) and Malet et al. (2005) on different soft rock-landslides. The challenge in understanding the hydrologic control of the behavior of landslides is the implication of the heterogeneity of the respective landslide body in numerical models (e.g. Wienhöfer et al., 2011) in order to get a universally valid plausibility. Especially preferential water infiltration paths which lead to abrupt hydrological, and therefore mechanical, changes of material properties are often unknown. On rock slopes, existing fractures (caused by freeze/thaw cycles) mark preferential water paths during strong rain events or snow melting periods and can cause their destabilization.

Beside thermal and hydrological changes, Schulz et al. (2009) observed that even weak variations of air pressure influence the dynamic of the fast-moving Slumgullion landslide (Colorado, US) which consists of sediments as well. Also the influence of strong earthquakes to slope stabilities is proven in several studies. For example, more than 10000 landslides were induced by the $M_{\mathrm{W}}=7.6 \mathrm{Chi}-\mathrm{Chi}$ earthquake in Taiwan in 1999 (e.g. Khazai and Sitar, 2004).

\subsection{The once-in-a-hundred-years rainfall event on 23 August 2005}

In August 2005, one of the most catastrophic rainfall and flood events in the last $100 \mathrm{yr}$ hit the entire Alpine region. The event caused many casualties and damages to infrastructure, communication routes and agriculture with an economic loss between 1-2 billion Euros (Beniston, 2006). At Heumoes slope, rainfall of $\sim 240 \mathrm{~mm}$ in $24 \mathrm{~h}$ was recorded on 23 August 2005. Beside the economical damages, the immense rain intensity caused several landslides in the entire Vorarlberg region and a few single rotational slides in the direct vicinity of the Heumoes slope. Caused by this intense rain event, the "Dornbirnerach" river, which drains the entire region of the Heumoes slope, swelled significantly with maximal outflow values of $246 \mathrm{~m}^{3}$ per second. The rise of the "Dornbirnerach" and its confluents on 23 August 2005 caused the last known damage in the area of the "Rappenlochschlucht" gorge: a small bridge was destroyed by huge rock blocks which were carried away by the immense masses of water of the "Ebniterach" river.

\subsection{Possible triggers of the "Rappenlochschlucht" rockfall event}

To investigate possible triggers of the destructive rockfall event in the "Rappenlochschlucht" gorge on 10 May 2011, several meteorological and hydrological data were analyzed. As the rock mass in the "Rappenlochschlucht" gorge was originally not the focus of our work, no reference data were available from the direct vicinity of that area. Nevertheless, we analyzed available reference data from the surrounding area.

The meteorological data were recorded at two weather stations: at the Heumoes slope and in the village of Ebnit in a distance of a few hundred meters (Fig. 1). According to the described possible triggers, we verified the temporal occurrence of the rockfall with recorded data of air temperature, air pressure, snow cover, precipitation and outflow of the "Dornbirnerach" river (Fig. 10). The outflow measuring device is located close to the city of Dornbirn at $467 \mathrm{~m}$ a.s.l. (Fig. 1), at river kilometer marker 13 and is serviced by authorities of the Vorarlberg province. The orographical catchment area 


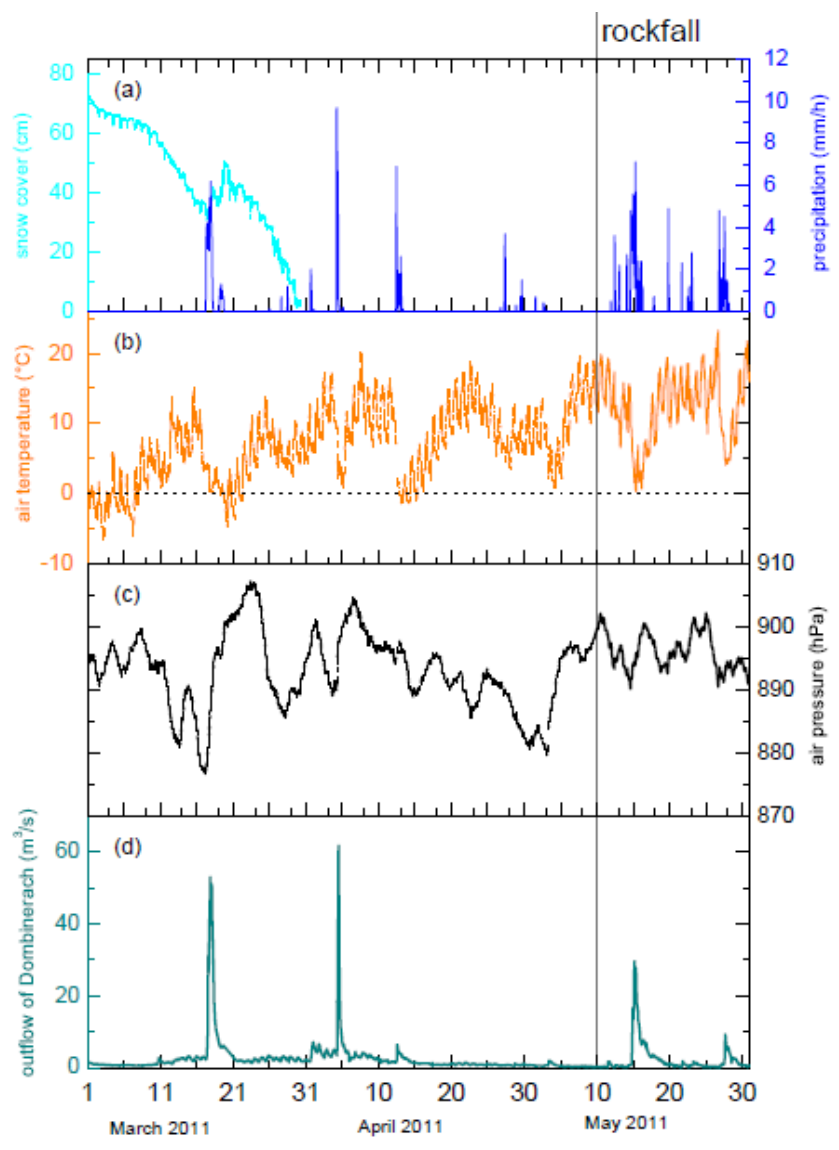

Fig. 10. Meteorological and hydrological data between March and May 2011: (a) snow cover and precipitation; (b) air temperature; (c) air pressure; (d) outflow of the "Dornbirnerach" river (Fig. 1). Highlighted is the rockfall occurrence on 10 May 2011.

of the "Dornbirnerach" river is estimated to be $53.2 \mathrm{~km}^{2}$; its outflow indicates the surface water flow of the entire area on a regional scale.

Figure 10 illustrates the snow cover, precipitation, air temperature, air pressure and the outflow of the "Dornbirnerach" river between March and May 2011. It shows that the snow melting period ended already at the end of March 2011 and therefore marks no possible trigger for the rockfall event. The strongest rain intensities were recorded at beginning of April 2011. In the week before the rockfall occurred, no precipitation was measured. Freeze/thaw cycles can be excluded as well as possible triggers as the last frost period occurred at beginning of April 2011. The variation of air pressure, which is very unlikely being a triggering factor, does not show significant anomalies in the specific time frame around 10 May 2011. The outflow of the "Dornbirnerach" river correlates well with higher rain intensities on 18 March, 5 April and 15 May 2011. In the time of the rockfall occurrence, no significant changes were recorded. In addition to the meteorological and hydrological data, we investigated the local seismicity as a possible trigger in that time period as well. The last local earthquake before rockfall generation occurred on 29 April 2011 with a magnitude of $M_{\mathrm{L}}=1.1$ in approximately $18 \mathrm{~km}$ distance to the "Rappenlochschlucht" gorge, so that a seismic trigger can be excluded as well. To summarize, contrary to the once-in-a-hundred-years-event in $\mathrm{Au}-$ gust 2005, a triggering factor of the rockfall event at the "Rappenlochschlucht" gorge on 10 May 2011 could not be identified and therefore remains unknown.

\section{Conclusions}

A massive rockfall with an estimated volume of approximately $15000 \mathrm{~m}^{3}$ occurred on 10 May 2011 in the "Rappenlochschlucht" gorge, Vorarlberg, Austria, and destroyed an important massive bridge construction. Using a permanent seismic network at the Heumoes slope in a distance of around $5 \mathrm{~km}$ to the "Rappenlochschlucht" gorge, we were able to record the rockfall. Beside the registration of the main rockfall event, we were able to identify two weaker rockfalls which occurred several hours before and whose signals show remarkable similarities to "avalanche" signals. The equivalent magnitude of the main event is estimated to be $M_{\mathrm{L}, \mathrm{eq}}=2.3$, while the magnitude of the weaker ones is comparable to $M_{\mathrm{L}, \mathrm{eq}}=0.0$. All rockfall events were located in the vicinity of the "Rappenlochschlucht" gorge.

Beside these "avalanche" signals, we observed fracture signals whose properties show remarkable similarities to fracture processes generated at the creeping Heumoes slope which was originally the area of interest for the seismic monitoring. But compared to the fracture events located at Heumoes slope, the observed fracture signals on 10 May 2011 show 5 to 10 times higher $t s-t p$ as well as a higher apparent velocity indicating a larger epicentral distance. These fracture signals, with local magnitudes of $-0.5<M_{\mathrm{L}}<0.4$, occurred up to approximately $5 \mathrm{~h}$ before the main rockfall was generated. Generally, these fractures occurred up to one hour before one of the three rockfalls. Also these fracture processes were located in the direct vicinity of the "Rappenlochschlucht" gorge by applying absolute and relative localization methods. We therefore interpret these signals as being precursory stress relief within the rock mass, or mass transferring processes, respectively, finally causing the destructive main rockfall event. This interpretation is supported by the fact that these specific types of fracture signals have never been observed in nearly two years of permanent seismic monitoring, so that other seismic source mechanisms can be excluded.

Several meteorological and hydrological data as well as the local seismicity during that period of time were analyzed in order to identify possible trigger mechanisms of the destructive rockfall event. Unfortunately, no triggering factor of the rockfall event could be identified and remains unknown. 
Acknowledgements. We thank Eberhard Claar, Patrick Blascheck, Benjamin Sick and Martina Gassenmeier for both, their assistance in development and field installation of the permanent seismic network, as well as for data management and data pre-processing. The meteorological data of the weather station at the Heumoes slope is provided by colleagues of the research unit "Grosshang". The meteorological data of the weather station in Ebnit, the hydrological data of the outflow of the "Dornbirnerach" as well as the Airborne Laser Scan of Figs. 1 and 9 are provided by the Land Vorarlberg. We thank Andreas Günther (Editor) as well as two anonymous reviewers for their improvements of the manuscript. This work was supported by the German Research Foundation (DFG) within the funded research unit FOR 581 "Grosshang" and within the funding programme Open Access Publishing.

Edited by: A. Günther

Reviewed by: two anonymous referees

\section{References}

Beniston, M.: August 2005 intense rainfall event in Switzerland: Not necessarily an anolog for strong convective events in a greenhouse climate, Geophys. Res. Lett., 33, L05701, doi:10.1029/2005GL025573, 2006.

Brückl, E. and Mertl, S.: Seismic Monitoring of Deep-Seated Mass Movements, Proc. of INTERPRAEVENT International Symposium "Disaster Mitigation of Debris Flows, Slope Failures and Landslides", Universal Academy Press, Inc., Tokyo, Japan, 571580, 2006

Deichmann, N. and Giardini, D.: Earthquakes induced by the stimulation of an enhanced geothermaö system below Basel (Switzerland), Seis. Res. Lett., 80, 784-798, 2009.

Depenthal, C. and Schmitt, G.: Monitoring of a landslide in Vorarlberg/Austria, in: Proc. Int. FIG Symp. on Deformation Measurements, 11th, Santorini (Thera) Island, Greece, 25-28 May 2003, edited by: Stiros, S. and Pytharouli, S., Geodesy and Geodetic Appl. Lab., Dep. of Civ. Eng., Patras Univ., Rio, Greece, 289295, 2003.

Fierz, C. and Lehning, M.: Assessment of the microstructure-based snow-cover model SNOWPACK: thermal and mechanical properties, Cold Reg. Sci. Technol., 33, 123-131, 2001.

Gomberg, J., Bodin, P., Savage, W., and Jackson, M. E.: Landslide faults and tectonic faults, analogs?: The Slumgullion earthflow, Colorado, Geology, 23, 41-44, 1995.

Gomberg, J., Schulz, W., Bodin, P., and Kean, J.: Seismic and geodetic signatures of fault slip at the Slumgullion Landslide Natural Laboratory, J. Geophys. Res., 116, B09404, doi:10.1029/2011JB008304, 2011.

Got, J.-L., Mourot, P., and Grangeon, J.: Pre-failure behaviour of an unstable limestone cliff from displacement and seismic data, Nat. Hazards Earth Syst. Sci., 10, 819-829, doi:10.5194/nhess10-819-2010, 2010.

Gruber, S. and Haeberli, W.: Permafrost in steep bedrock slopes and its temperature-related destabilization following climate change, J. Geophys. Res., 112, 1-10, doi:10.1029/2006JF000547, 2007.

Häge, M. and Joswig, M.: Untersuchung der Lokalisierungsgenauigkeit von Kleinarrays anhand induzierter Seismizität während der Stimulationsphase des Deep-Heat-MiningProjektes in Basel, DGG Mitteilungen 1/2011, 24-30, 2011.
Hainzl, S., Kraft, T., Wassermann, J., Igel, H., and Schmedes, E.: Evidence for rainfall-triggered earthquake activity, Geophys. J. Int., 33, L19303, doi:10.1029/2006GL027642, 2006.

Hanson, S. and Hoelzle, M.: The thermal regime of the active layer at the Murtèl rock glacier based on data from 2002, Permafrost Periglac. Process., 15, 273-282, 2004.

Harris, C., Arenson, L. U., Christiansen, H. H., Etzelmüller, B., Frauenfelder, R., Gruber, S., Haeberli, W., Hauck, C., Hölzle, M., Humlum, O., Isaksen, K., Kääb, A., Kern-Lütschg, M. A., Lehning, M., Matsuoka, N., Murton, J. B., Nötzli, J., Phillips, M., Ross, N., Seppälä, M., Springman, S. M., and Vonder Mühll, D.: Permafrost and climate in Europe: Monitoring and modelling thermal, geomorphological and geotechnical responses, EarthSci. Rev., 92, 117-171, doi:10.1016/j.earscirev.2008.12.002, 2009.

Helmstetter, A. and Garambois, S.: Seismic monitoring of Séchilienne rockslide (French Alps): Analysis of seismic signals and their correlation with rainfalls, J. Geophys. Res., 15, F03016, doi:10.1029/2009JF001532, 2010.

Husen, S., Bachmann, C., and Giardini, D.: Locally triggered seismicity in the central Swiss Alps following the large rainfall event of August 2005, Geophys. J. Int., 171, 1126-1134, 2007.

Joswig, M.: Nanoseismic Monitoring fills the gap between microseismic networks and passive seismic, First Break, 26, 121-128, 2008.

Kääb, A., Huggel, C., Fischer, L., Guex, S., Paul, F., Roer, I., Salzmann, N., Schlaefli, S., Schmutz, K., Schneider, D., Strozzi, T., and Weidmann, Y.: Remote sensing of glacier- and permafrostrelated hazards in high mountains: an overview, Nat. Hazards Earth Syst. Sci., 5, 527-554, doi:10.5194/nhess-5-527-2005, 2005.

Kahn, D.: Hydro-Fractured Reservoirs: A Study using DoubleDifference Location Techniques, PhD-thesis, Duke University, 2008.

Keller, F. and Gubler, H. U.: Interaction between snow cover and high mountain permafrost at Murtèl/Corvatsch, Swiss Alps, The 6th International Conference on Permafrost, Beijing, China, 332-337, 1993.

Kennett, B. L. N. and Engdahl, E. R.: Traveltimes for global earthquake location and phase identification, Geophys. J. Int., 105, 429-465, 1991.

Khazai, B. and Sitar, N.: Evaluation of factors controlling earthquake-induced landslides caused by Chi-Chi earthquake and comparison with the Northridge and Loma Prieta events, Eng. Geol., 71, 79-95, 2004.

Levy, C., Baillet, L., Jongmans, D., Mourot, P., and Hantz, D.: The dynamic response of the chamousset rock column (Western Alps, France) before its collapse, J. Geophys. Res., 115, F04043, doi:10.1029/2009JF001606, 2010.

Levy, C., Jongmans, D., and Baillet, L.: Analysis of seismic signals recorded on a prone-to-fall rock column (Vercors massif, French Alps), Geophys. J. Int., 186, 296-310, doi:10.1111/j.1365246X.2011.05046.x, 2011.

Lindenmaier, F., Zehe, E., Dittfurth, A., and Ihringer, J.: Process identification at a slow-moving landslide in the Vorarlberg Alps, Hydrol. Process., 19, 1635-1651, 2005.

Luetschg, M. A. and Haeberli, W.: Permafrost evolution in the Swiss Alps in a changing climate and the role of the snowcover, Nor. J. Geogr., 59, 77-83, 2005. 
Malet, J.-P., van Asch, Th. W. J., van Beek, R., and Maquaire, O.: Forecasting the behaviour of complex landslides with a spatially distributed hydrological model, Nat. Hazards Earth Syst. Sci., 5, 71-85, doi:10.5194/nhess-5-71-2005, 2005.

Matsuoka, N.: Diurnal freeze-thaw depth in rockwalls: field measurements and theoretical considerations, Earth Surf. Proc. Landf., 19, 423-435, 1994.

Matsuoka, N. and Sakai, H.: Rockfall activity from an alpine cliff during thawing periods, Geomorphology, 28, 309-328, 1999.

Mellor, M.: Engineering properties of snow, J. Glaciol., 19, 15-66, 1977.

Oberhauser, R.: Der geologische Aufbau Österreichs, SpringerVerlag, Wien, 1980.

Prick, A.: Frost weathering and rock fall in an arctic environment, Longyearbyen, Svalbard, available at: http://research.iarc.uaf. edu/NICOP/DVD/ICOP2003Permafrost/Pdf/Chapter_159.pdf (latest access: 3 November 2012), 2003.

Rapp, A.: Recent development of mountain slopes in Kärkevagge and surroundings, Northern Scandinavia, Geogr. Ann., 42, 65200, 1960.

Roth, M., Dietrich, M., Blikra, L. H., and Lecomte, I.: Seismic monitoring of the unstable rock slope at Åknes, Norway, NORSAR, Report for the International Centre for Geohazards, 2005.

Schulz, W. H., Kean, J. W., and Wang, G.: Landslide movement in southwest Colorado triggered by atmospheric tides, Nat. Geosci., 2, 863-866, doi:10.1038/ngeo659, 2009.

Spillmann, T., Maurer, H., Green, A. G., Heincke, B., Willenberg, H., and Husen, S.: Microseismic investigations of an unstable mountain slope in the Swiss Alps, J. Geophys. Res., 112, B07301, doi:10.1029/2006JB004723, 2007.

Stoffel, M., Lièvre, I., Conus, D., Grichting, M. A., Raetzo, H., Gärtner, H. W., and Monbaron, M.: 400 years of debris-flow activity and triggering weather conditions: Ritigraben, Valais, Switzerland, Arct., Antarc., Alp. Res., 37, 387-395, 2005.

Sturm, M., Holmgren, J., König, M., and Morris, K.: The thermal conductivity of seasonal snow, J. Glaciol., 43, 26-41, 1997.

Travelletti, J., Oppikofer, T., Delacourt, C., Malet, J.-P., and Jaboyedoff, M.: Monitoring landslides displacements during a controlled rain experiment using a long-range terrestrial laser scanning (TLS), The International Archives of the Photogrammetry, Remote Sensing and Spatial Information Sciences, Vol. XXXVII, Part B5, 485-490, 2008.
Tsaparas, I., Rahardjo, H., Toll, D. G., and Leong, E. C.: Controlling parameters for rainfall-induced Landslides, Comput. Geosci., 29, 1-27, 2002.

van Asch, T. W. J., Buma, J., and van Beek, L. P. H.: A view on some hydrological triggering systems in landslides, Geomorphology, 30, 25-32, 1999.

Walter, M. and Joswig, M.: Seismic monitoring of fracture processes generated by a creeping landslide in the Vorarlberg Alps, First Break, 26, 131-135, 2008.

Walter, M. and Joswig, M.: Seismic characterization of slope dynamics caused by softrock-landslides: The Super-Sauze case study, in: Proceedings of the International Conference on Landslide Processes: from geomorphologic mapping to dynamic modelling, edited by: Malet, J.-P., Remaître, A., and Boogard, T., Strasbourg, CERG Editions, 215-220, 2009.

Walter, M., Niethammer, U., Rothmund, S., and Joswig, M.: Joint analysis of the Super-Sauze (French Alps) mudslide by nanoseismic monitoring and UAV-based remote sensing, First Break, 27, 75-82, 2009.

Walter, M., Walser, M., and Joswig, M.: Mapping RainfallTriggered Slidequakes and Seismic Landslide-Volume Estimation at Heumoes slope, Vadose Zone J., 10, 487-495, 2011.

Walter, M., Arnhardt, C., and Joswig, M.: Seismic monitoring of rockfalls, slide quakes, and fissure development at the SuperSauze mudslide, French Alps, Eng. Geol., 128, 12-22, 2012.

Wienhöfer, J., Lindenmaier, F., and Zehe, E.: Challenges in Understanding the Hydrologic Controls on the Mobility of SlowMoving Landslides, Vadose Zone J., 10, 496-511, 2011.

Wust-Bloch, H. and Joswig, M.: Pre-collapse identification of sinkholes in unconsolidated media at Dead Sea area by "nanoseismic monitoring" (graphical jackknife location of weak sources by few, low-SNR records), Geophys. J. Int., 167, 1220-1232, 2006.

Zhang, T.: Influence of the seasonal snow cover on the ground thermal regime: an overview, Rev. Geophys., 43, RG4002, doi:10.1029/2004RG000157, 2005. 